\title{
Vacuolating encephalopathy and retinopathy associated with a nodavirus-like agent: a probable cause of mass mortality of cultured larval and juvenile Atlantic halibut Hippoglossus hippoglossus
}

\author{
Sindre Grotmol ${ }^{1, *}$, Geir K. Totland ${ }^{2}$, Kristin Thorud ${ }^{3}$, Brit K. Hjeltnes ${ }^{1}$ \\ ${ }^{1}$ Institute of Marine Research, Department of Aquaculture, PO Box 1870 Nordnes, N-5024 Bergen, Norway \\ ${ }^{2}$ University of Bergen, Institute of Zoology, Allégt. 41, N-5007 Bergen, Norway \\ ${ }^{3}$ Central Veterinary Laboratory, Department of Fish Health, PO Box 1856 Dep., N-0033 Oslo, Norway
}

\begin{abstract}
Reared larval and juvenile Atlantic halibut Hippoglossus hippoglossus collected during incidences of mass mortality in 2 hatcheries were studied by light and electron microscopy. A vacuolating encephalopathy and retinopathy as well as endocardial lesions were observed. By transmission electron microscopy isometric, spherical, unenveloped virus particles with mean capsid diameters of approximately $25 \mathrm{~nm}$ were detected. The virions were found intracytoplasmically in semicrystalline arrays or as membrane-associated aggregates and single particles. Infection could be observed in neurons, astrocytes, oligodendrocytes, microglia/macrophages, lymphocyte-like cells, vascular endothelium, endocardial endothelium, myocardial myocytes and in the mesothelium of the epicardium. Specific immunolabeling was obtained in affected tissues on immunohistochemistry applying primary antisera against nodaviruses isolated from the striped jack Pseudocaranx dentex and the sea bass Dicentrarchus labrax. We suggest that the mortality was caused by a nodavirus-like agent and that this disease of the Atlantic halibut is closely related to diseases termed viral nervous necrosis (VNN), viral encephalopathy and retinopathy, and fish encephalitis, which have been associated with mass mortality in numerous cultured marine teleost species. In Atlantic halibut, viral endocardial lesions were a constant finding, suggesting that viremia may be an important factor in the pathogenesis of the infection.
\end{abstract}

KEY WORDS: Atlantic halibut · Fish · Immunohistochemistry · Electron microscopy · Nodavirus · Viral encephalopathy and retinopathy $\cdot$ Neuronal vacuolation

\section{INTRODUCTION}

All over the world, the cultivation of marine fish species is on the increase (Anonymous 1994). In Norway, systems for culturing the Atlantic halibut Hippoglossus hippoglossus have been developed and an industrial scale production has been established. The main challenge facing halibut farming has been that of achieving high survival rates during early life stages. Major difficulties have been related to nutrition in the startfeeding and weaning periods. Losses due to infectious diseases have primarily been caused by Vibrio species, certain strains of Flexibacter and infectious pancreatic necrosis virus (IPNV) (Mortensen et al. 1990, Bergh et

•E-mail: sindre.grotmol@imr.no al. 1992, Skiftesvik \& Bergh 1993, Biering et al. 1994). Several parasitic infections of reared halibut have been reported (Nilsen \& Bristow 1994, Nilsen 1995, Nilsen et al. 1995), but the economic importance of these is still uncertain.

In the summer of 1995 acute high mortality occurred in 2 large commercial hatcheries and juvenile rearing facilities for Atlantic halibut. In one of the fish farms the larvae were extensively reared in floating mesh bags in a lagoon. The other facility was an intensive land-based fish nursery where nearly all the larvae died. A preliminary diagnostic investigation indicated a relationship to vacuolating encephalopathy and retinopathy (Grotmol et al. 1995). Nodaviriosis or similar disease has been reported in larvae and juveniles of several other cultured marine teleost species (Glaze- 
brook et al 1990, Yoshikoshi \& Inoue 1990, Bloch et al. 1991, Breuil et al. 1991, Mori et al. 1991, 1992, Renault et al. 1991, Munday et al. 1992, Arimoto et al. 1993, Nakai et al. 1994, Nguyen et al. 1994, Muroga 1995, Boonyaratpalin et al. 1996, Fukuda et al. 1996). The aim of the present study was to give a description of the disease in Atlantic halibut, with special emphasis on its pathomorphological and immunohistochemical characteristics.

\section{MATERIALS AND METHODS}

Fish and rearing conditions. Halibut larvae and juveniles (metamorphosed fish) were collected from the 2 rearing facilities. In one of the nurseries, the larvae were reared extensively in floating mesh-bags in a lagoon and fed zooplankton harvested from the surrounding sea. The other production facility was a land-based unit with more intensive production where the larvae were fed a combination of cultured Artemia and harvested marine zooplankton. The mortality was recorded.

Behaviour and gross pathological signs were observed in affected fish. A range of individuals was sampled in different developmental stages ranging from $2 \mathrm{~cm}$ pelagic larvae to $5 \mathrm{~cm}$ metamorphosed juveniles.

Microbiology and parasitology. Samples of the kidney were plated on blood agar base no. 2 (Difco, Detroit, MI, USA) containing 5\% defibrinized bovine blood with and without $2 \% \mathrm{NaCl}$, and on marine agar (Difco). Incubation was carried out at 22 and $15^{\circ} \mathrm{C}$ for at least $5 \mathrm{~d}$.

For virological examination, cultures of epithelioma papillosum cyprini cells (EPC), chinook salmon embryo cells (CHSE) and blue gill fibroblast cells (BF2) were inoculated with homogenate of whole fish and incubated at $20^{\circ} \mathrm{C}$. Parallel samples were inoculated after neutralization with anti-IPNV rabbit serum. The cells were examined by light microscopy 1 wk after a second passage to new cell cultures.

Wet mounts of gills, skin and intestines were examined by light microscopy for the presence of parasites.

Tissue preparation for light microscopy. Fixation and embedding: For histopathological and immunohistochemical examination, whole larvae $(n=40)$ were fixed in phosphate buffered $10 \%$ formalin $(\mathrm{pH} 7.4)$, dehydrated through a graded ethanol-xylene series, and embedded in paraffin wax. Sagittal and transverse sections, 3 to $5 \mu \mathrm{m}$ thick, were stained with haematoxylin/eosin (H\&E) or haematoxylin/erythrocin-B/saffron (HES). Whole larvae $(n=10)$ were also fixed in a cacodylate buffered solution of $1 \%$ formaldehyde and $2.5 \%$ glutaraldehyde (see 'Tissue processing for transmission electron microscopy'). These specimens were dehydrated and embedded in Historesin (LKB Produkter $\mathrm{AB}$, Bromma, Sweden), and semithin sections (1 to $2 \mu \mathrm{m}$ ) were stained with a solution of toluidine blue (Philpott 1966).

Immunofluorescence: An indirect fluorescent antibody technique (Nakai et al. 1991), using an antistriped jack nervous necrosis virus (anti-SJNNV) rabbit serum, was applied to sections of formalin-fixed paraffin embedded whole larvae $(n=10)$. The anti-SJNNV rabbit serum was provided by Dr Nakai (University of Hiroshima, Japan) and had previously been applied in several studies on nodavirus (Munday et al. 1994, Nakai et al. 1994, Nguyen et al. 1994, 1996). The antibody was raised against purified virions of SJNNV according to procedures described previously (Arimoto et al. 1992, Mori et al. 1992). Cross-reactions with viruses of other families have not been detected. The sec-

Figs. 1 to 8. Hippoglossus hippoglossus. Immunohistochemical staining of paraffin sections. Fig. 1. Retina. Vacuolated cells (arrow) were most conspicuous in the amacrine cells of the bipolar layer and in the neurons of the ganglionic layer (arrowhead). Note also small vacuoles in the rod and cone layer (RC) and in bipolar neurons proper. Avidin biotin alkaline phosphatase method, anti-SJNNV serum and Mayer's haematoxylin counterstain. Scale bar $=100 \mu \mathrm{m}$. Fig. 2. Retina stained immunohistochemically with anti-DIEV serum. Note the similar staining pattern as in Fig. 1. Avidin biotin peroxidase complex method and Mayer's haematoxylin counterstain. Scale bar $=100 \mu \mathrm{m}$. Fig. 3. The eye. In some specimens ophthalmitis with numerous mononuclear cells in the anterior and posterior chamber was found. Some of the mononuclear cells adhered to the inner surface of the retina and some were observed infiltrated in the retinal tissue. Note the immunolabeling in the infiltrated retina. Avidin biotin alkaline phosphatase method, antiSJNNV serum and Mayer's haematoxylin counterstain. Scale bar $=300 \mu \mathrm{m}$. Fig. 4 . Retina and corpus vitreum. The arrows show immunofluorescent granules in mononuclear cells at the inner surface of the retina. The granules probably represent cytoplasmic viral aggregates. Indirect fluorescent antibody technique (anti-SJNNV serum). Scale bar $=50 \mu \mathrm{m}$. Fig. 5. Nervus opticus. Immunolabeling of oligodendrocytes arranged in rows (arrowheads). Avidin biotin alkaline phosphatase, anti-SJNNV serum and Mayer's haematoxylin counterstain. Scale bar $=200 \mu \mathrm{m}$. Fig. 6. Brain and spinal cord. Massive and diffuse immunolabeling and vacuolation in all major parts of the brain and cranial spinal cord. Avidin biotin alkaline phosphatase method, anti-SJNNV and Mayer's haematoxylin counterstain. Scale bar $=600 \mu \mathrm{m}$. Fig. 7. Optic tectum. Vacuolation (V) and immunolabeling of neurons in the stratum periventriculare. Avidin biotin alkaline phosphatase method, anti-SJNNV serum and Mayer's haematoxylin counterstain. Scale bar $=50 \mu \mathrm{m}$. Fig. 8. Diencephalon. Degeneration and vacuolation of neurons and gliosis in the grey matter. In the periphery of some of the vacuoles (arrows) immunolabeled granules are seen. Note also the immunolabeled cells without vacuoles (white arrowheads). Avidin biotin alkaline phosphatase method, anti-SJNNV serum and Mayer's haematoxylin counterstain. Scale bar $=150 \mu \mathrm{m}$ 

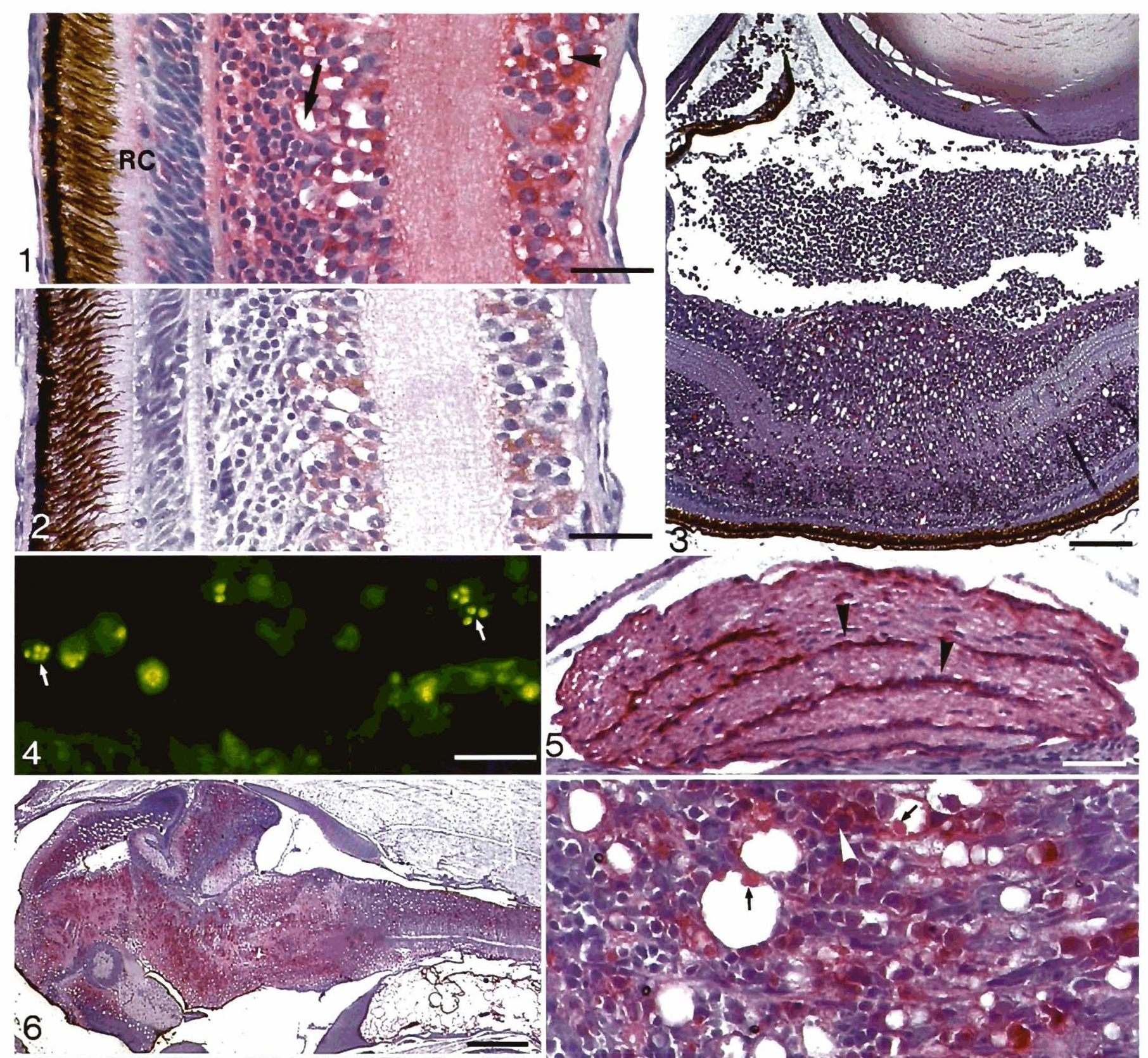

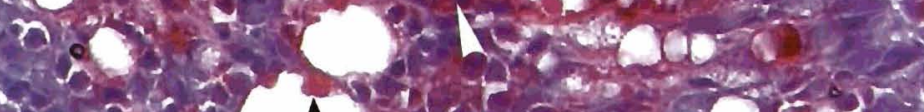

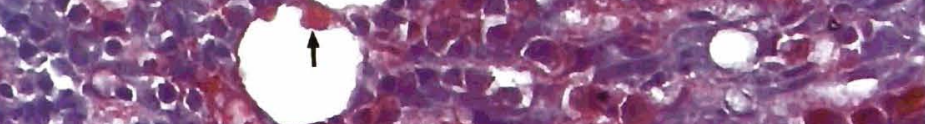

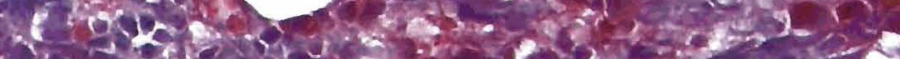

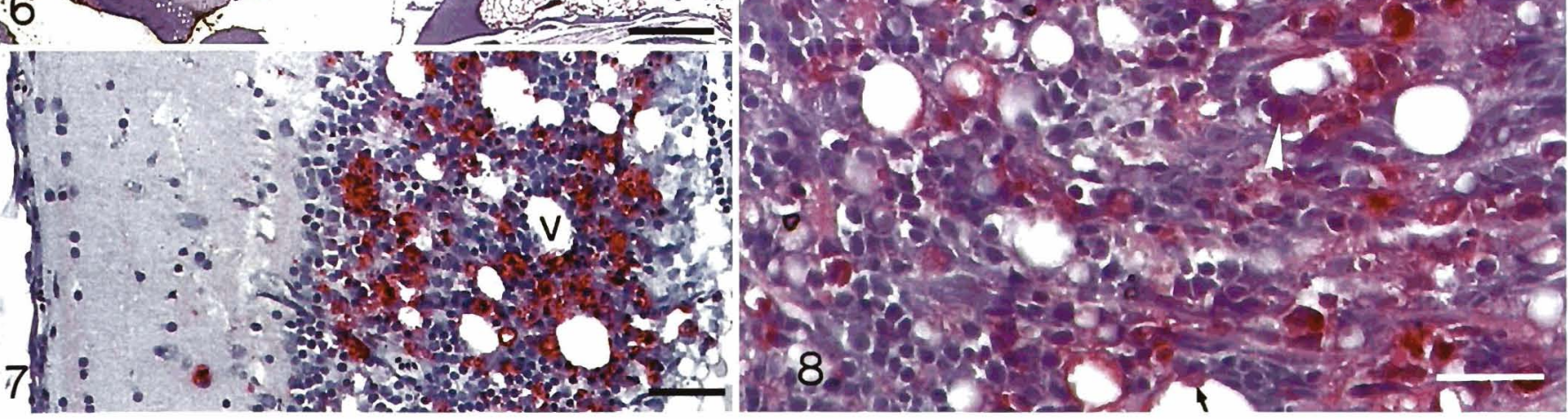
4 .

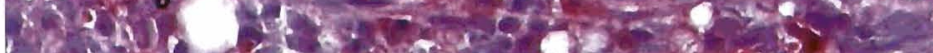


tions were first deparaffinized at 58 to $59^{\circ} \mathrm{C}$ for $30 \mathrm{~min}$ washed in 2 xylene baths, and rehydrated through a series of decreasing concentrations of ethanol $1100 \%$, $96 \%, 70 \%, 50 \%$ ). Then the sections were covered with a solution of $0.1 \%$ trypsin (Sigma Co., St. Louis, MO, USA) in $0.01 \mathrm{M}$ PBS ( $\mathrm{pH} 7.4$ ) for $30 \mathrm{~min}$ at $37^{\circ} \mathrm{C}$, washed 5 times with cold phosphate-buffered saline (PBS) and incubated for $30 \mathrm{~min}$ at $37^{\circ} \mathrm{C}$ with the primary antibody (anti-SJNNV) diluted 1:100 in 0.01 M PBS containing $1 \%$ bovine serum albumin (BSA). The sections were washed in cold PBS and reincubated for $30 \mathrm{~min}$ at $37^{\circ} \mathrm{C}$ with secondary antibody (FITC-conjugated swine Ig to rabbit Ig; DAKO A/S, Glostrup, Denmark). The sections were then washed in PBS, mounted in non-fluorescent glycerin, and examined with a Olympus AH-3 fluorescence microscope. The specificity of the staining was confirmed by omitting the primary antibody, and by replacing the anti-SJNNV serum with a nonimmune serum (normaì rabbit serum).

Immunohistochemistry: Two protocols were employed:

(1) Immunohistochemistry using the anti-SJNNV rabbit serum was carried out according to established methods (Hsu et al. 1981, Evensen 1993). Sections of formalin-fixed paraffin-embedded halibut samples (n $=30$ ) were deparaffinized and rehydrated. Sections of Historesin Plus-embedded halibut were used directly according to the following protocol. Nonspecific antibody binding sites were blocked by covering the sections with a solution of $5 \%$ BSA in Tris-buffered saline (TBS, pH 7.4) for $5 \mathrm{~min}$. The solution was blotted off the slides and the anti-SJNNV serum was incubated at a dilution of $1: 1500$ in $2.5 \%$ BSA in TBS for $30 \mathrm{~min}$. After washing for $5 \mathrm{~min}$ in TBS, the secondary antibody, biotinylated goat anti-rabbit immunoglobulin (DAKO) diluted $1: 300$ in $2.5 \% \mathrm{BSA}$ in TBS, was added and incubated for $30 \mathrm{~min}$. After washing in TBS, streptavidin alkaline phosphatase (diluted 1:1000; Boehringer, Mannheim, Germany) was added and incubated at room temperature for $30 \mathrm{~min}$. After washing, Fast Red (1 $\mathrm{g} \mathrm{l}^{-1}$; Sigma) and naphthol AS-MX-phosphate $\left(0.2 \mathrm{~g} \mathrm{l}^{-1}\right.$; Sigma) with $1 \mathrm{mM}$ levamisole (Sigma) as inhibitor in 0.1 M TBS were added and allowed to develop for $20 \mathrm{~min}$. After washing in tap water, sections were counterstained with Mayer's haematoxylin and mounted in an aqueous mounting medium (Aquamount, BDH Laboratory Supplies, England).

(2) The procedure was performed with an anti-sea bass Dicentrarchus labrax encephalitis virus (antiDlEV) rabbit serum, using a universal kit for primary rabbit immune sera (SIM 918; Sigma). Sections of formalin-fixed paraffin-embedded halibut samples $(\mathrm{n}=10)$ were deparaffinized and rehydrated. Endogenous peroxidase activity was blocked by incubating the slides in a $3 \%$ solution of hydrogen peroxide in distilled water for 5 min. After washing in PBS ( $\mathrm{pH} 7.4$ ) for $5 \mathrm{~min}$, nonspecific antibody binding sites were blocked by incubating the sections in a blocking solution for $10 \mathrm{~min}$. The solution was blotted off the slides and the anti-DlEV rabbit serum was incubated at a dilution of 1:5000 in PBS-BSA solution (0.5 mg BSA per $\mathrm{ml}$ PBS) for $60 \mathrm{~min}$. After washing the slides twice for $3 \mathrm{~min}$ in a PBS-Tween 20 solution and once in PBS for $3 \mathrm{~min}$, the secondary antibody, biotinylated goat antirabbit serum solution, was added and incubated for 20 min. After washing in PBS, avidine peroxidase was added and incubated at room temperature for $20 \mathrm{~min}$. After washing, the slides were incubated for $20 \mathrm{~min}$ with the peroxidase substrate solution (AEC chromogene). After washing in tap water, sections were counterstained with Mayer's haematoxylin and mounted in an aqueous mounting mediun (Aquamount).

All incubations were performed at room temperature in a humidity chamber unless otherwise stated. Controls included use of nonimmune serum (normal rabbit serum) at the same dilution as the immune rabbit serum. Tissue sections from uninfected Atlantic halibut were also incubated with immune and nonimmune serum. The endpoint dilution values (the highest dilution of the primary antibody that gives a positive reaction discernible from background) were determined after $30 \mathrm{~min}$ incubation at room temperature (Petrusz 1983)

Tissue processing for transmission electron microscopy. For transmission electron microscopy, samples from the brain, spinal cord, left eye, gills, heart (sinus venosus, atrium, ventricle) and liver were carefully dissected from 10 fish submerged in fixative, using a binocular microscope. A volume of $100 \mathrm{ml}$ fixative was composed of $10 \mathrm{ml} 10 \%$ formaldehyde, $10 \mathrm{ml} 25 \%$ glutaraldehyde, $20 \mathrm{ml} 0.2 \mathrm{M}$ cacodylate buffer and $60 \mathrm{ml}$ PBS (pH 7.35). The whole eye and thin slices of the other tissues were rinsed in buffer and postfixed in $1 \% \mathrm{OsO}_{4}$, dehydrated in ethanol, and embedded in Epon 812 (Fluca Chemie AB, Switzerland). Semithin sections ( $1 \mu \mathrm{m}$ thick) for light microscopy were stained with a solution of toluidine blue. Ultrathin sections were contrasted in uranyl acetate and lead citrate and observed in a Jeol CX100 transmission electron microscope.

\section{RESULTS}

\section{Estimation of mortality}

In the land-based fish farm, close to $100 \%$ mortality was registered in an initial population of approximately 400000 larvae. The pattern of the mortality curve was typical of an acute outbreak and most fish 
died within $1 \mathrm{wk}$ after the beginning of the rise in the mortality rate. After 2 mo the fish in all tanks of this facility became affected. Most larvae died in the period of early metamorphosis, approximately 60 to $70 \mathrm{~d}$ posthatching. In some tanks, mortality accompanied by similar clinical signs was observed both in earlier stages of larval development and in juvenile fish. In the production plant in the lagoon, the initial population was approximately 600000 larvae, but only 150000 larvae were harvested from the bags.

\section{Clinical signs and gross pathology}

The clinical signs first seen in the larvae were reduced skin pigmentation and empty, transparent intestines due to reduced food intake. In juvenile fish, darkening of the skin was seen. Abnormal behaviour such as spiral swimming and looping was observed in the early stages of a disease outbreak. Severely diseased larvae and juveniles became lethargic, often lying upside down on the bottom. Occasionally tonic spasms of the myotomal musculature could be observed, resulting in temporary flexion of the body.

\section{Microbiology and parasitology}

Neither bacteriological nor parasitological examination revealed any specific findings. No viral cytopathogenic effect was observed in the inoculated cells.

\section{Histopathology}

\section{Light microscopy}

The light microscopical examination of both apparently normal and sick fish revealed lesions in the retina, brain and spinal cord, in ganglia of the peripheral nervous system, in the gills and in the heart. Specific immunostaining was obtained in affected tissues with both the anti-SJNNV and the anti-DlEV sera (Figs. 1 \& 2). No lesions were detected in other organs.

All fish examined, except for one, had degenerative and vacuolated lesions in the retina (spongiform retinopathy). The extent of vacuolation of retinal tissue varied. Large vacuoles were exclusively located in the amacrine cells within the bipolar nuclear layer and in the neurons of the ganglionic layer (Figs. 1 \& 2). In these layers pronounced immunolabeling was observed both in neurons containing vacuoles and in non-vacuolated neurons. Intensively immunolabeled granules were observed in the cytoplasm of some neurons. Small, scattered vacuoles were occasionally observed in rod and cone cells and in the bipolar neurons proper. Within the plexiform layers and in the neuropil of the nuclear layers, faint immunolabeling was observed (Fig. 1). In some specimens ophthalmitis was observed with mononuclear inflammatory cells in the anterior and posterior chamber of the eye, in contact with the lens and the retinal surface or the cells had infiltrated the retinal tissue (retinitis) (Fig. 3). The mononuclear inflammatory cells had varying morphology, some being typically lymphocyte-like and others resembling macrophages. In some of the mononuclear cells suspended in the corpus vitreum, immunoreactive granules were detected (Fig. 4). The optic nerve also showed immunolabeling (Fig. 5).

In the brain and the spinal cord, vacuolation and immunolabeling was most conspicuous in the grey matter (Figs. 6 to 11). Some fish showed diffuse vacuolation and immunolabeling (Fig. 6), while others exibited multifocal lesions. When immunolabeling was apparent in the central nervous system (CNS) (in $85 \%$ of the fish), the optic tectum was always affected. Furthermore, the optic tectum was the part of the CNS that in most fish showed the most pronounced immunolabeling and severe vacuolation (Fig. 7). In about one-third of the fish that had lesions confined to the optic tectum, only a few additional cells in the pretectal nuclei of the diencephalon were immunolabeled. The rest of the fish with lesions in the optic tectum had diffuse or multifocal lesions in the telencephalon, diencephalon, cerebellum, myencephalon and cranial part of the spinal cord. In the cerebellum, vacuolation was less widespread, but neuropathy and immunolabeling was frequently seen in the large pericarya of Purkinje cells (Fig. 9).

In the severely vacuolated tissue of the CNS, immunolabeling was observed in the cytoplasm of degenerate cells (Figs. 8 \& 10), along the periphery of vacuoles and in the neuropil. Unidentifiable cells containing large vacuoles had peripherally displaced pyknotic nuclei. The largest vacuoles had diameters of about $50 \mu \mathrm{m}$ and exceeded the size of large neurons. Basophilic and immunolabeled granules were observed in some of the vacuoles, often adherent to the limiting membrane (Fig. 8). The tissue surrounding severely vacuolated lesions seemed distorted and compressed.

In areas without pronounced vacuolation, immunolabeling was detected in the neuropil, in shrunken neurons with pyknotic nuclei and in neurons with seemingly normal morphology (Fig. 8). In the H\&Estained sections, some neurons appeared chromatolytic with swollen and homogenously stained cytoplasm lacking basophilic Nissl bodies (not shown). Other neurons were shrunken, with increased basophilia of the pericarya. Varying degrees of gliosis were seen in both vacuolated and nonvacuolated areas of the CNS. In the peripheral nervous system, vacuola- 

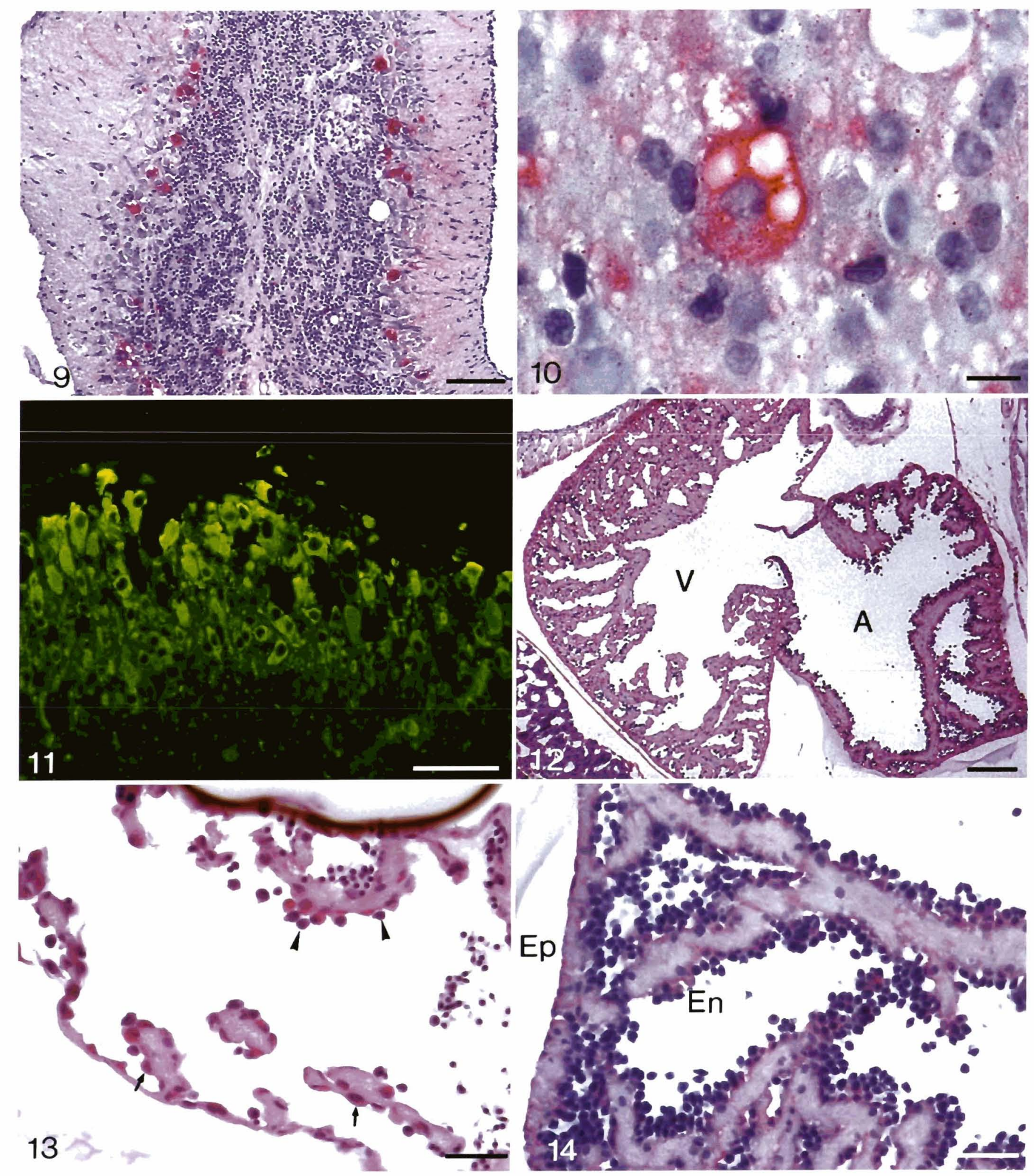

Ep
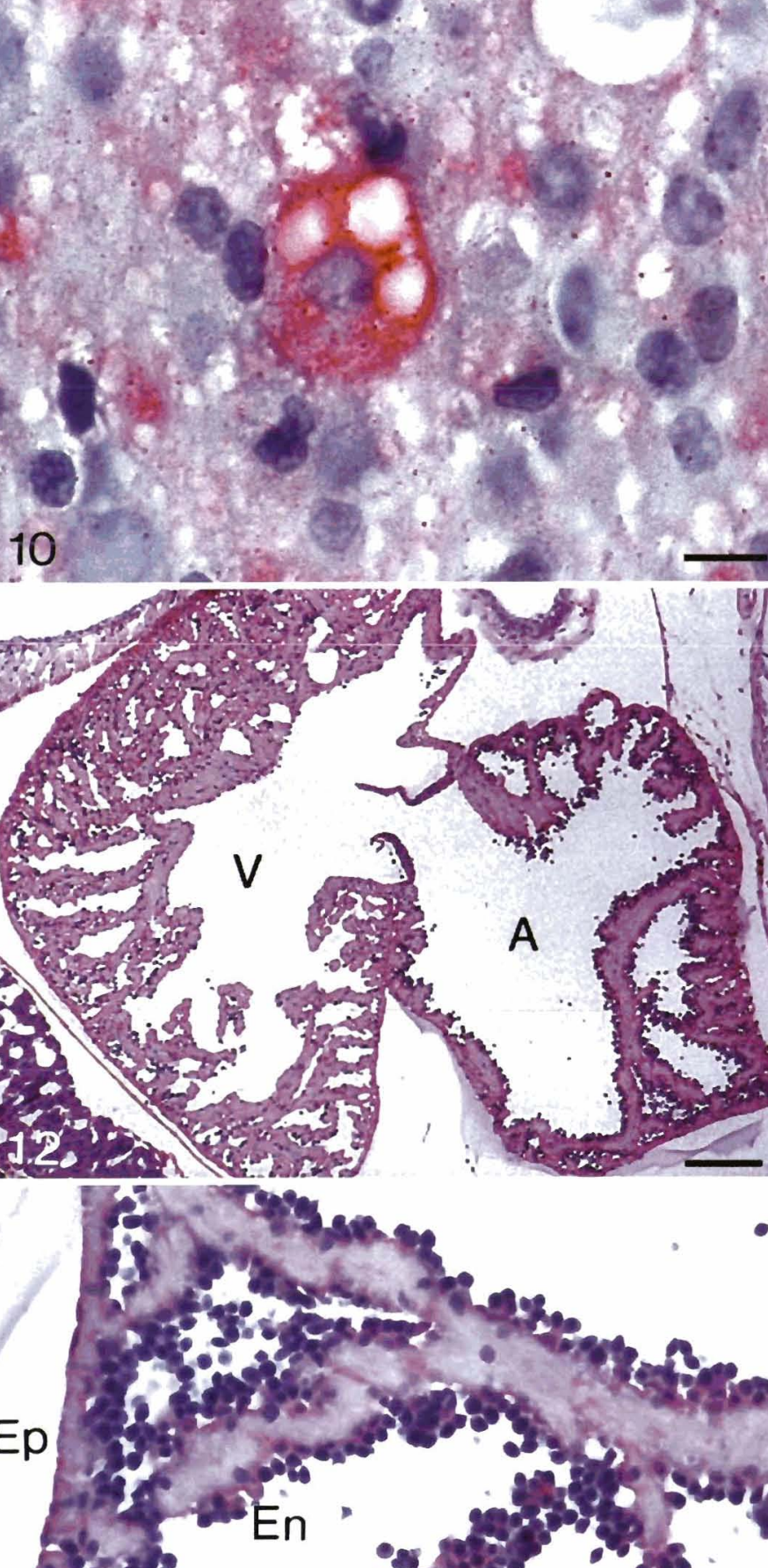

Ex+8

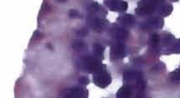

in 43 $-$<smiles></smiles>

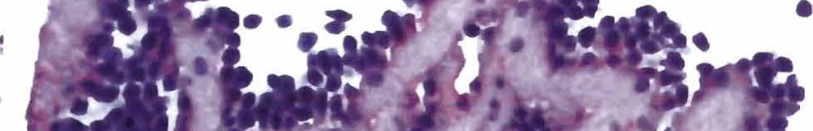

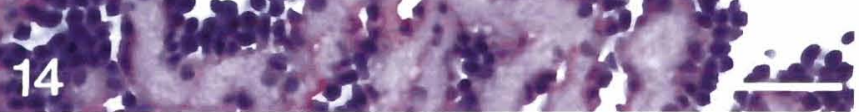


Figs. 9 to 14. Hippoglossus hippoglossus. Immunohistochemical staining of paraffin sections. Fig. 9. Cerebellum with specific immunolabeling of degenerate Purkinje cells. Avidin biotin alkaline phosphatase method, anti-SJNNV serum and Mayer's haematoxylin counterstain. Scale bar $=200 \mu \mathrm{m}$. Fig. 10. Degenerate neuron of the myelencephalon containing several vacuoles and immunolabeled neuroplasm. Avidin biotin alkaline phosphatase method, anti-SJNNV serum and Mayer's haematoxylin counterstain. Scale bar $=20 \mu \mathrm{m}$. Fig. 11. Longitudinal section of the spinal cord showing dorsal horn neurons with immunofluorescence in the neuroplasm. Indirect fluorescent antibody technique, anti-SJNNV serum. Scale bar $=50 \mu \mathrm{m}$. Fig. 12 . Diffuse margination of lymphocyte-like cells in both the atrium (A) and the ventricle (V) of the heart. Avidin biotin alkaline phosphatase method, anti-SJNNV serum and Mayer's haematoxylin counterstain. Scale bar $=300 \mu \mathrm{m}$. Fig. 13. In the sinus venosus immunolabeled endothelial cells (arrows) were frequently observed. Note that some of the lymphocyte-like cells also show distinct immunolabeling (arrowheads). Avidin biotin alkaline phosphatase method, anti-SJNNV serum and Mayer's haematoxylin counterstain. Scale bar $=100 \mu \mathrm{m}$. Fig. 14. Atrium of the heart with diffuse margination of lymphocyte-like cells to the endocardial lining. Note immunolabeling of epi- (Ep), myo- and endocardium (En). Avidin biotin alkaline phosphatase method, anti-SJNNV serum and Mayer's haematoxylin counterstain. Scale bar $=100 \mu \mathrm{m}$

tion was observed in neurons of both cephalic ganglia of the sympathetic nervous system (Fig. 15) and in neurons of the spinal ganglia (Fig. 16). Affected ganglia showed immunolabeling (not shown).
In the gills, degeneration and necrosis of pillar cells were observed. The affected pillar cells had frequently lost contact with adjacent pillar cells, leaving large blood lacunae in the secondary lamellae (Fig. 17).

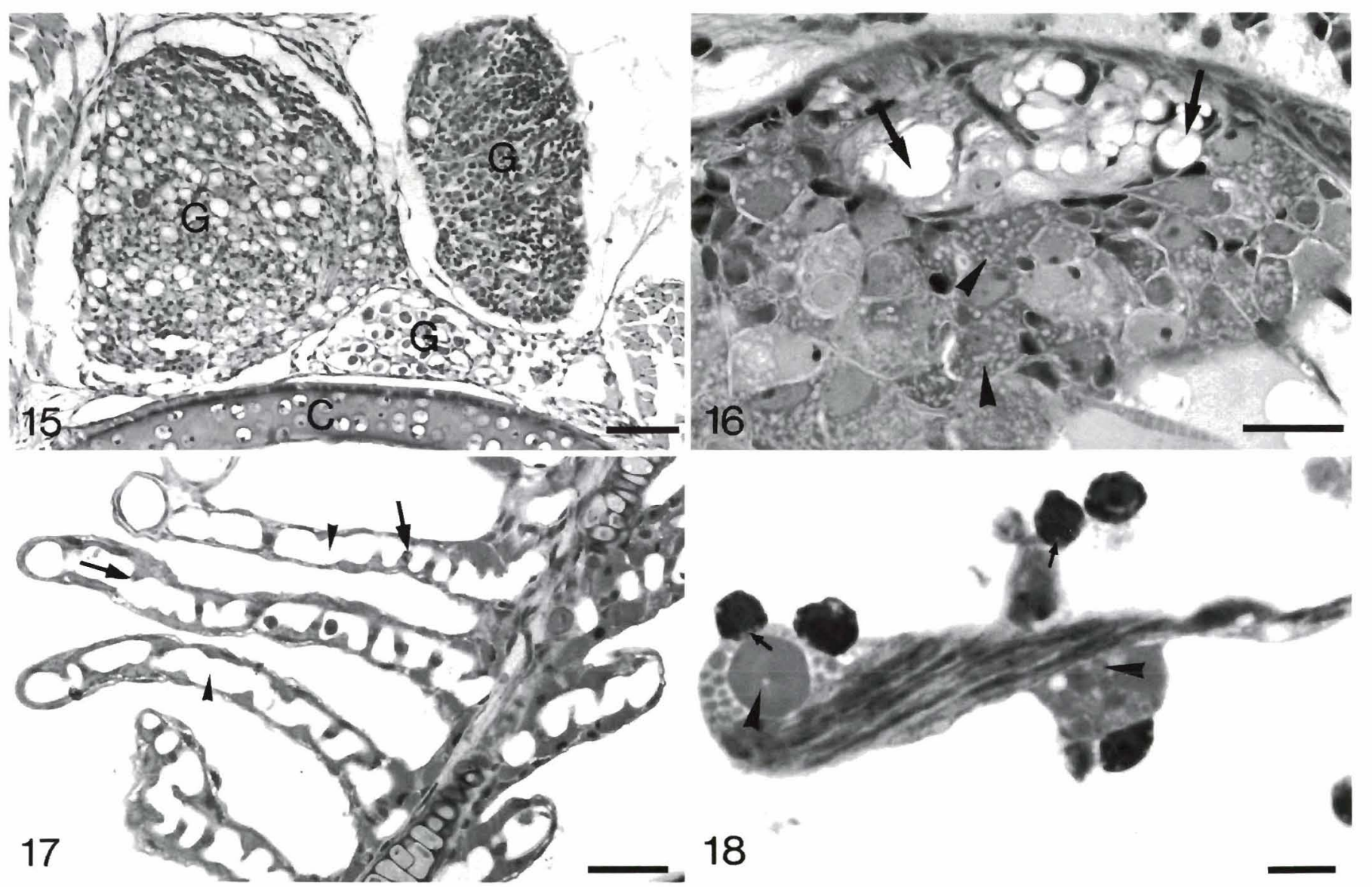

Figs. 15 to 18. Hippoglossus hippoglossus. Semithin sections of Historesin-embedded whole larvae stained with toluidine blue. Fig. 15. Cephalic sympathetic ganglia. Most of the neurons in 2 of the ganglia show degeneration and vacuolation. C: cranium, G: ganglion. Scale bar $=150 \mu \mathrm{m}$. Fig. 16. Spinal ganglion. In this ganglion large vacuoles were found in some neurons (arrows) while others contained numerous small vacuoles (arrowheads). Scale bar $=50 \mu \mathrm{m}$. Fig. 17. Gills. Lacunae (arrowheads) were found within the secondary lamellae due to degeneration of the pillar cells (arrows). Note the anemic state with few blood cells. Scale bar $=100 \mu \mathrm{m}$. Fig. 18. Sinus venosus. Protruding endothelial cells with multiple spherical cytoplasmic inclusions (arrowheads) were observed. Lymphocyte-like cells adhered to the luminal surface of the endothelium. Note the clear vesicles in the lymphocyte-like cells adjacent to the surface of contact (arrows). Scale bar $=20 \mu \mathrm{m}$ 
Faint immunolabeling was observed in some pillar cells (not shown).

Early stages of an inflammatory lesion (endocarditis) with margination of lymphocyte-like cells on the endothelial lining of the endocardium was observed in all the fish examined (Figs. 12 to 14). Extravasation of the lymphocyte-like cells was not prominent. The endocardial endothelial cells contained multiple weakly basophilic inclusions of varying size (Fig. 18). The endocardial endothelium and the epicardial mesothelium of most specimens showed immunolabeling (Figs. $13 \& 14$ ). In some of the fish, an anemic state reflected by the presence of few blood cells in the heart cavities and gill vasculature (Figs. 12 \& 17).

The presence of endocardial lesions, retinopathy and/ or encephalomyelopathy revealed 3 patterns: (1) In one of $40 \mathrm{fish}$, the endocardial lesions were observed with neither the retina nor the CNS being affected. (2) In the rest of the fish, the endocardial lesions were accompanied by retinopathy, and (3) $85 \%$ of these fish also showed encephalopathy and/or myelopathy. Fish with retinopathy showed immunolabeling of the optic nerve.

\section{Electron microscopy}

In affected tissue, virus particles were found both extra- and intracellularly. The virus particles were isometric, spherical and unenveloped with a capsid diameter of approximately $25 \pm 2.5 \mathrm{~nm}$ (Fig. 19). Virus particles were detected in degenerate neurons (Fig. 20), endothelial cells (Fig. 21), oligodendrocytes, astrocytes (Fig. 22) and microglia/macrophages. The virions were found in the cytoplasm, either as free particles or associated with membranes. The membrane associated virions were often studded on the endoplasmic reticulum (ER) (Fig. 23) or densely packed in pleomorphic membrane-bound bodies (inclusions), some with a semicrystalline viral matrix (Fig. 19).

Neurons showed varying but often severe signs of degeneration (Figs. 20, $23 \& 24$ ). Stacks of organised roughER were usually lacking and the ER cisternae appeared dilated. Cells in early phases of degeneration often contained small vacuoles confined within the cisternae of distorted rough-ER. The mitochondria were swollen with disorganized cristae. Severe neuropathy was associated with disintegation of both the ER and mitochondria.

Free virus particles were observed in both dendritic and axonic processes. In microglial cells, numerous, large membrane-bound bodies containing virus were observed. Some cell bodies appeared dark (electrondense) with the cytoplasm packed with virus. The identity of these cells was difficult to determine.

In the CNS, vacuoles were found in neurons, but were also observed in oligodendrocytes and possibly in microglia and astrocytes. The small vacuoles were evenly distributed throughout the cytoplasm (Fig. 20) and the observations of vacuoles coincided with the presence of virus particles in the cell. In the periphery of the vacuoles, membrane-bound viral aggregates could be observed (Fig. 24) and virions were frequently found studded on the limiting membrane. Discontinuous membranes could be observed between adjacent vacuoles. Complete disintegration of virusinfected cells with disruption of their plasmalemma was common in severely vacuolated loci. Extracellularly, virus particles often formed regular necklace-like structures between the plasma membranes of adjacent cells (Fig. 20). Endothelial cells of the capillaries in affected brain tissue contained numerous virus particles both free in the cytoplasm and within small membrane-bound bodies (Fig. 21). Free virus particles were also detected in the astrocyte processes surrounding the endothelial cells (Fig. 22). The pillar cells of the gills were degenerate or necrotic and in some of them virus-like particles were observed (not shown).

In the sinus venosus and atrium of the heart, the endothelial lining was lacking in large areas. Most of the remaining degenerate endothelial cells were swollen and protruded into the lumen. The cytoplasm of these cells contained numerous virus particles (Fig. 25) and multiple membrane-bound cytoplasmic inclusions with an amorphous matrix. Some of the lymphocyte-like cells adherent to the endothelium had an electrondense cytoplasm packed with viruses (Fig. 25). These cells also contained clear vesicles in the cytoplasm, especially in the area adjacent to endothelial cells. Virus-like particles were also observed in myocytes and in mesothelial cells of the epicardium (Fig. 26).

Figs. 19 to 22. Hippoglossus hippoglossus. Electron micrographs of brain tissue. Fig. 19. Membrane-bound viral aggregate and free virions in the cytoplasm of a neuron. A necklace-like arrangement of virions (arrowheads) can be seen in areas between adjacent membranes. Arrows show crystalline array arangement. Scale bar $=0.5 \mu \mathrm{m}$. The insert in the upper right corner is a high power magnification of a crystalline array of virus particles. Scale bar $=100 \mathrm{~nm}$. Fig. 20. Degenerate neuron of the diencephalon, containing myriads of free cytoplasmic virus particles and multiple, small vacuoles (V) within cisternae of endoplasmic reticulum. Note also the virus particles in the intercellular space (arrowheads). Scale bar $=1 \mu \mathrm{m}$. Fig. 21. In infected nervous tissue, the endothelium of capillaries contained free virus particles (arrowheads) and membrane-bound viral aggregates (arrows). Scale bar $=1 \mu \mathrm{m}$. Fig. 22. The endothelial cell (E) contains free cytoplasmic virus particles. In the adjacent astrocytic process (Ap), free virus particle can also be seen. Scale bar $=0.5 \mu \mathrm{m}$ 


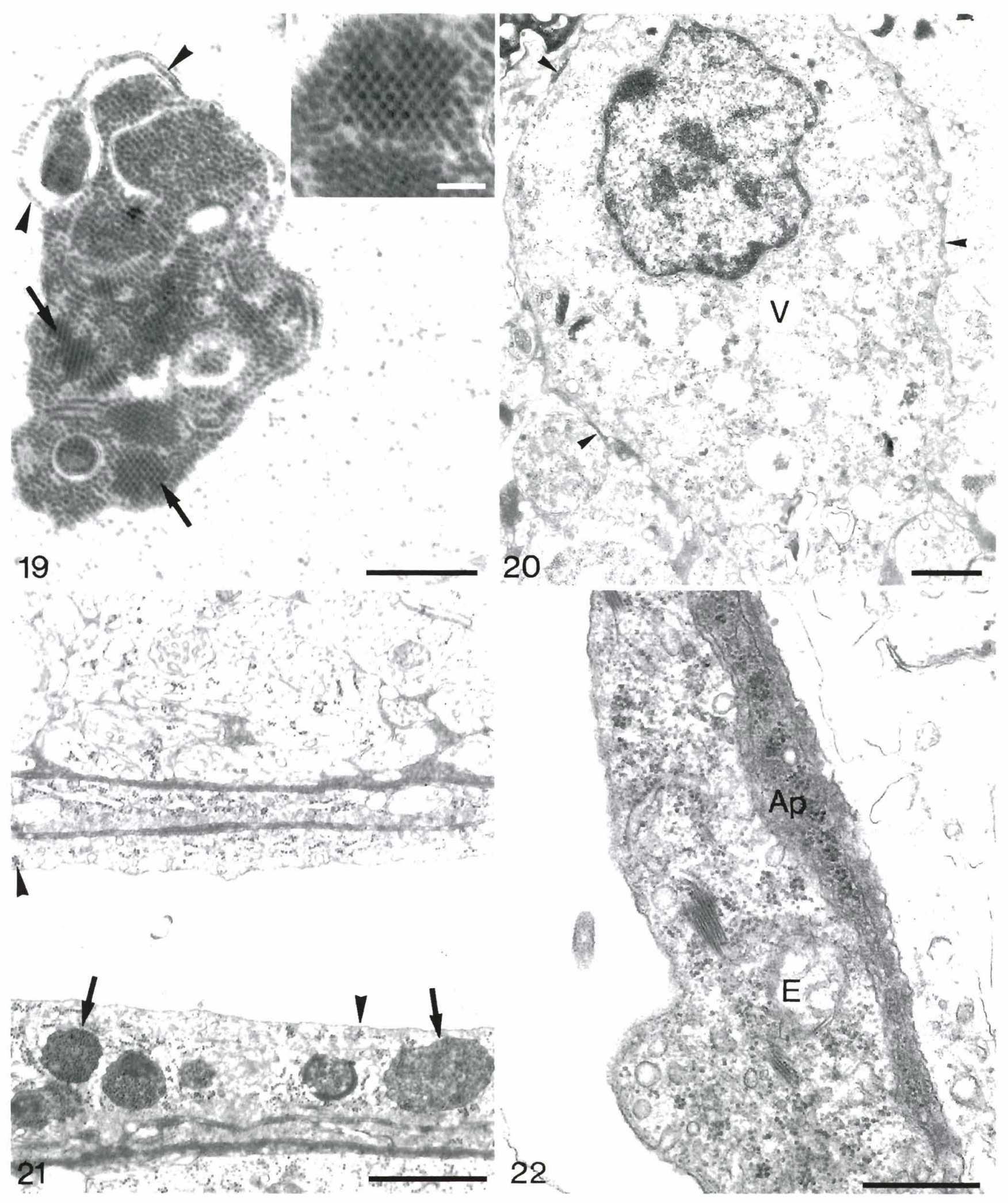




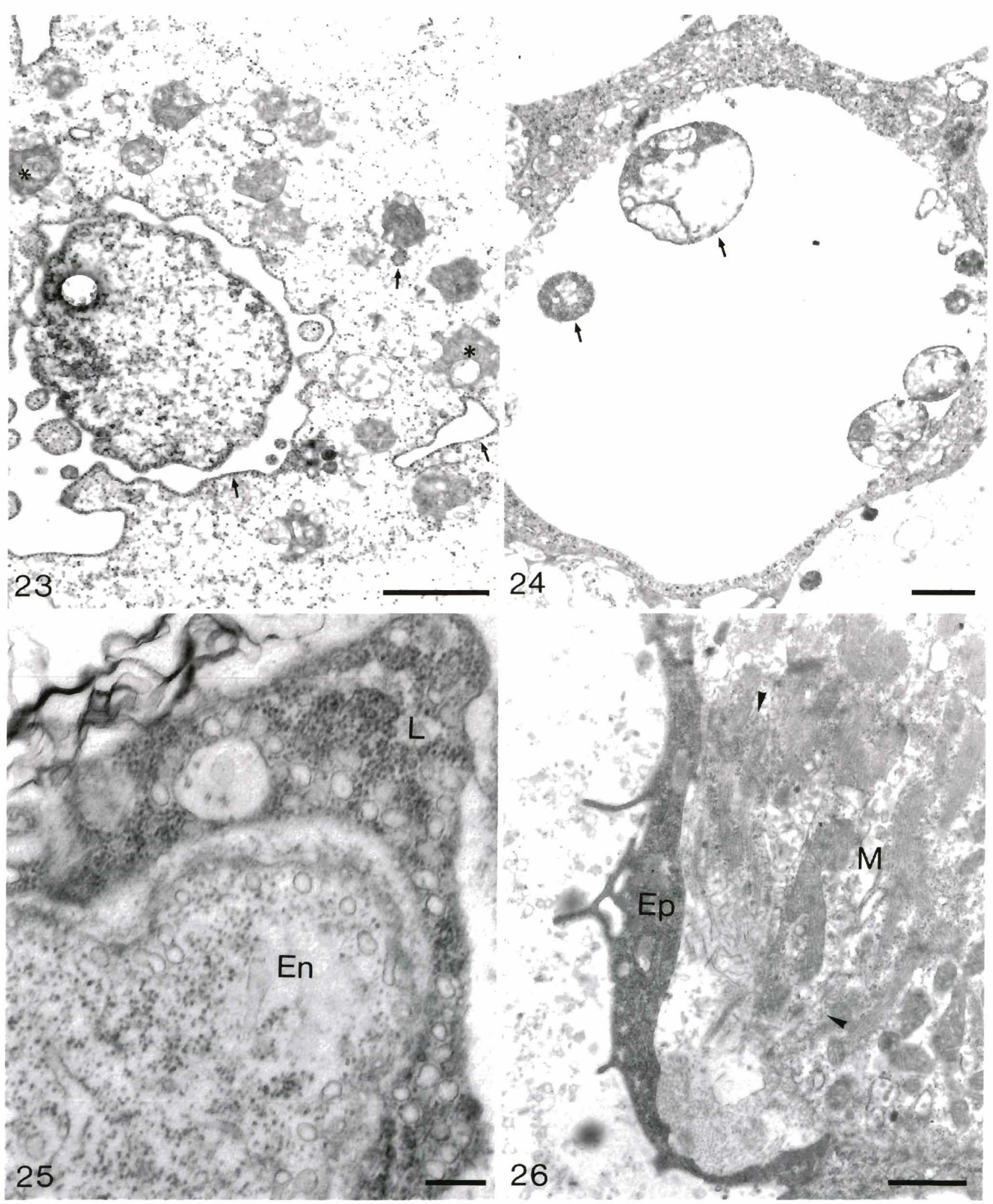


Figs. 23 to 26. Hippoglossus hippoglossus. Electron micrographs of brain and heart tissue. Fig. 23. Diencephalon. A neuron containing distorted membranes of endoplasmic reticulum (arrows) and degenerate mitochondria (*). Note the even arrangement of virus particles along the membranes (arrows). Scale bar $=0.5 \mu \mathrm{m}$. Fig. 24. Tectum opticum. A neuron of the stratum periventriculare containing membraneous bodies with virus particles (arrows) along the periphery of large vacuoles. The membraneous bodies are probably equivalent to the immunolabeled granules observed in vacuoles by light microscopy. Scale bar $=1 \mu \mathrm{m}$. Fig. 25. Apex of degenerate endocardial endothelial cell (En) surrounded by processes of a lymphocyte-like cell (L). Both cells contain numerous free virus particles. Scale bar $=0.25 \mu \mathrm{m}$. Fig. 26. A degenerate, electron-dense mesothelial cell of the epicardium (Ep). Its cytoplasm is packed with virus particles. Note that the degenerate myocytes (M) also contain free virus particles (arrowheads). Scale bar $=1 \mu \mathrm{m}$

In the liver the endothelial lining of the sinusoids was lacking in large areas. No prominent pathological changes or virus-like particles were observed in the hepatocytes.

\section{DISCUSSION}

The present study suggests that a nodavirus-like agent can infect cultured Atlantic halibut and cause disease with neurological symptoms leading to mass mortality. Pathomorphologically the disease is characterized as a vacuolating encephalomyelopathy and retinopathy as well as by the endocardial lesions. Disease with similar symptoms, epizootiology and lesions of nervous tissue has been reported in larvae and juveniles of several other cultured marine teleost species (Glazebrook et al. 1990, Yoshikoshi \& Inoue 1990, Bloch et al. 1991, Breuil et al. 1991, Mori et al. 1991, 1992, Renault et al. 1991, Munday et al. 1992, Arimoto et al. 1993, Nakai et al. 1994, Nguyen et al. 1994, Muroga 1995, Boonyaratpalin et al. 1996, Fukuda et al. 1996). The disease has variously been called viral nervous necrosis (VNN) (Yoshikoshi \& Inoue 1990, Mori et al. 1991, Arimoto et al. 1993, Nakai et al. 1994, Nguyen et al. 1994, Fukuda et al. 1996), viral fish encephalitis (Breuil et al. 1991), encephalomyelitis (Bloch et al. 1991), or viral encephalopathy and retinopathy (VER) (Munday et al. 1992, Anonymous 1995, Boonyaratpalin et al. 1996). Based on our results, we suggest that the disease observed in Atlantic halibut is closely related to the diseases described in the above-mentioned reports. In what follows we refer to this disease complex as VER-like.

The virus particles detected in Atlantic halibut had similar transmission electron microscopy-morphological characteristics to those described in other species affected by VER-like disease. Unenveloped virus particles, with diameters in the range of 20 to $34 \mathrm{~nm}$, have been identified in nervous tissue of the affected species. The specific immunolabeling obtained in our study shows that the virus of Atlantic halibut is antigenically related to SJNNV and DIEV. SJNNV (Mori et al. 1992) and the fish encephalitis viruses of sea bass and barramundi (Comps et al. 1994) have been iso- lated from affected fish and classified as belonging to the Nodaviridae. These nodaviruses are antigenetically related (Munday et al. 1994, Anonymous 1995). Our results thus indicate that the virus detected in Atlantic halibut may be related to SJNNV and DIEV and therefore possibly be a nodavirus.

The present study indicates that the perikaria of neurons contain a large amount of virus before the onset of vacuolation. Myriads of virions were detected in distended cisternae of rough endoplasmic reticulum or densely packed within membrane-bound bodies. The association of virions and membrane structures implies that the viral structural protein was formed on rough endoplasmic reticulum and that assembly of virions may take place within its cisternae. This may lead to destruction of the endoplasmic reticulum and the formation of vacuoles and membrane-bound aggregates of virus. As the vacuoles increase in size, they may coalesce, resulting in status spongiosus and disintegration of neurons. The coexistence of vacuoles and virus in these cells indicates that the formation of vacuoles is caused by the viral cytopathogenicity itself rather than by other terminal events.

Hitherto, VER-like disease has primarily been associated with lesions resulting from viral neurotropism. Endocardial lesions associated with nodaviriosis have not been reported from other species. In the present study a strict viral neurotropism was not evident and virions were also observed in the endothelium, mesothelium and myocytes of the heart, in the capillary endothelia of the CNS and in glial cells. In other species virus particles have also been observed in cell types other than neurons (Yoshikoshi \& Inoue 1990, Bloch et al. 1991, Nguyen et al. 1996), further supporting the notion that aquatic nodaviruses may have a wide range of host cells.

The pathogenesis of nodaviriosis has yet to be fully unravelled. It has been suggested that the virus enters the medial spinal cord through afferent nerves from the skin and that the infection spreads from here, in a craniad direction to the brain and retina and in a caudad direction in the spinal cord (Nguyen et al. 1996). In Atlantic halibut virus-like particles were observed in the pillar cells, indicating a possible organ of entry. Alternatively, the pillar cells are infected by virus 
already in the bloodstream, in the same manner as other endothelial cells. The constant observation of virus-associated endocardial lesions suggests that viremia may be an important factor in the pathogenesis of VER. In our study, even fish without any pathological changes in the CNS had endocardial lesions. This implies that viremia caused by liberation of virions from endothelial cells may precede infection of the nervous system. The endocardial lesions may thus represent early sites for infection. The high frequency of retinal infection (pattern 2) and of coaffection of the retina, the optic nerve and the optic tectum (pattern 3 ) indicates that the spread of the virus from the eye to the CNS via the optic nerve may occur. Haematogenic spreading of the infection directly from the vascular bed to the CNS may also occur. Vertical viral transmission from subclinically infected striped jack spawners to their offspring has been demonstrated (Mushiake et al. 1992, 1993, 1994). Persistent and subclinical nodavirus infections of adult fish not developing VER may be a result of sustained viral replication in endothelial cells.

Acknowledgements. We thank Dr T. Nakai for kindly providing the anti-SJNNV serum and Dr $\varnothing$. Evensen and Dr F. Baudin-Laurencin for help with the immunohistochemistry. We also thank Ingrid Uglenes, Nina Ellingsen, Randi Terland, Anneri Sundstrøm and Elly Soltvedt for excellent technical assistance. Dr Ø. Evensen is also thanked for constructive criticism of the manuscript.

\section{LITERATURE CITED}

Anonymous (1994) Aquaculture production 1986-1994. FAO Fisheries Circular No. 815. Rev 6, Rome

Anonymous (1995) Viral encephalopathy and retinopathy. In: OIE Fish Diseases Commission (ed) Diagnostic manual of aquatic animal diseases, 1st edn. Office International des Epizooties (OIE), Paris, p 85-90

Arimoto M, Mori K, Nakai T, Muroga K, Furusawa I (1993) Pathogenicity of the causative agent of viral nervous necrosis disease in striped jack, Pseudocaranx dentex. J Fish Dis 16:461-469

Arimoto M, Mushiake K, Mizuta Y, Nakai T, Muroga K, Furusawa I (1992) Detection of striped jack nervous necrosis virus (SJNNV) by enzyme-linked immunosorbent assay (ELISA). Fish Pathol 27:191-195

Bergh $\varnothing$, Hansen GH, Taxt RE (1992) Experimental infection of eggs and yolk sac larvae of halibut, Hippoglossus hippoglossus L. J Fish Dis 15:379-391

Biering E, Nilsen F, Rødseth OM, Glette J (1994) Susceptibility of Atlantic halibut Hippoglossus hippoglossus to infectious pancreatic necrosis virus. Dis Aquat Org 20: $183-190$

Bloch B, Gravningen K, Larsen JL (1991) Encephalomyelitis among turbot associated with a picornavirus-like agent. Dis Aquat Org 10:65-70

Boonyaratpalin S, Supamattaya K, Kasornchandra J, Hoffmann RW (1996) Picorna-like virus associated with mortality and spongious encephalopathy in grouper Epinephelus malabaricus. Dis Aquat Org 26:75-80
Breuil G, Bonami JF, Pichot Y (1991) Viral infection (picornalike virus) associated with mass mortalities in hatcheryreared sea-bass (Dicentrarchus labrax) larvae and juveniles. Aquaculture 97:109-116

Comps M, Pepin JF, Bonami JR (1994) Purification and characterization of two fish encephalitis virus (FEV) infecting Lates calcarifer and Dicentrarchus labrax. Aquaculture 123:1-10

Evensen $\varnothing$ (1993) An immunohistochemical study on the cytogenetic origin of pulmonary multinucleate giant cells in porcine dermatosis vegitans. Vet Pathol 31:162-170

Fukada Y, Nguyen HD, Furuhashi M, Nakai T (1996) Mass mortality of cultured sevenband grouper, Epinepheulus septemfasciatus, associated with viral nervous necrosis Fish Pathol 31:165-170

Glazebrook JS, Heasman MP, de Beer SW (1990) Picorna-like viral particles associated with mass mortalities in larval barramundi, Lates calcarifer Bloch. J Fish Dis 13:245-249

Grotmol S, Totland GK, Kvellestad A, Fjell K, Olsen AB (1995) Mass mortality of larval and juvenile hatchery-reared halibut (Hippoglossus hippoglossus L.) associated with the presence of virus-like particles in vacuolated lesions in the central nervous system and retina. Bull Eur Assoc Fish Pathol 15:176-180

Hsu SM, Raine L, Fanger H (1981) Use of an avidin-biotinperoxidase complex $(\mathrm{ABC})$ in immunoperoxidase techniques: a comparison between $\mathrm{ABC}$ and unlabelled antibody (PAP) procedures. J Histochem Cytochem 29 $577-580$

Mori K, Nakai T, Muroga K, Arimoto M, Mushiake K, Furusawa I (1992) Properties of a new virus belonging to Nodaviridae found in larval striped jack (Pseudocaranx dentex) with nervous necrosis. Virology 187:368-371

Mori K, Nakai T, Nagahara M, Muroga K, Mekuchi T, Kanno $T$ (1991) A viral disease in hatchery-reared larvae and juveniles of redspotted grouper. Fish Pathol 26:209-210

Mortensen S, Hjeltnes B, Rødseth OM, Krogsrud J, Christie KE (1990) Infectious pancreatic necrosis virus, serotype N1, isolated from Norwegian halibut (Hippoglossus hippoglossus), turbot (Scophthalmus maximus) and scallops (Pecten maximus). Bull Eur Assoc Fish Pathol 10:42

Munday BL, Langdon JS, Hyatt A, Humphry JD (1992) Mass mortality associated with a viral-induced vacuolating encephalopathy and retinopathy of larval and juvenile barramundi, Lates calcarifer Bloch. Aquaculture 103: $197-211$

Munday BL, Nakai T, Nguyen HD (1994) Antigenic relationship of the picornalike virus of larval barramundi, Lates calcarifer Bloch to the nodavirus of larval striped jack, Pseudocaranx dentex (Bloch \& Schneider). Aust Vet J 71: 385

Muroga K (1995) Viral and bacterial diseases in larval and juvenile marine fish and shellfish: a review. Fish Pathol 30:71-85

Mushiake K, Arimoto M, Furusawa T, Nakai T, Muroga K (1992) Detection of antibodies against striped jack nervous necrosis virus (SJNNV) from brood stocks of striped jack. Nippon Suisan Gakkaishi 58:2351-2356

Mushiake K, Nakai T, Muroga K, Sekiya S, Furusawa I (1993) Viral nervous necrosis (VNN) of striped jack: effects of plasma antibody level of spawners and spawning conditions on the occurrence of the disease in their offsprings. Suisan Zoshoku 41:327-332

Mushiake KT, Nishizawa K, Nakai T, Furusawa I, Muroga K (1994) Control of VNN in striped jack: selection of spawners based on the detection of SJNNV gene by polymerase chain reaction (PCR). Fish Pathol 29:177-182 
Nakai T, Mori K, Muroga K, Mecuchi T (1991) Diagnosis of viral epidermal hyperplasia of Japanese flounder larvae by fluorescent antibody technique. Nippon Suisan Gakkaishi 57:1507-1510

Nakai T, Nguyen HD, Nishizawa T, Muroga K, Arimoto M, Ootsuki K (1994) Occurrence of viral nervous necrosis in kelp grouper and tiger puffer. Fish Pathol 29:211-212

Nguyen HD, Mekuchi $T$, Imura $K$, Nakai $T$, Nishizawa $T$, Muroga K (1994) Occurrence of viral nervous necrosis (VNN) in hatchery-reared juvenile Japanese flounder Paralichthys olivaceus. Fish Sci 60:551-554

Nguyen HD, Nakai T, Muroga K (1996) Progression of striped jack nervous necrosis virus (SJNNV) infection in naturally and experimentally infected striped jack Pseudocaranx dentex larvae. Dis Aquat Org 24:99-105

Nilsen F (1995) Description of Trichodina hippoglossí n. sp. from farmed Atlantic halibut larvae Hippoglossus hippoglossus. Dis Aquat Org 21:209-214

Nilsen F, Bristow GA (1994) Microsporidiosis in farmed Atlantic halibut larvae (Hippoglossus hippoglossus L.) due to Pleistophora sp. Proc Int Symp Aquat Anim Health Sept $4-8$, Seattle, p 46

Responsible Subject Editor: J.-A. Leong, Corvallis, Oregon, USA
Nilsen F, Næss A, Nylund A (1995) Observations on an intranuclear microsporidian in lymphoblasts from farmed Atlantic halibut larvae (Hippoglossus hippoglossus L.). J Euk Microbiol 42:131-135

Petrusz P (1983) Essential requirements for the validity of immunocytochemical staining procedures. J Histochem Cytochem 31:177-179

Philpott DE (1966) A rapid method for staining plastic-embedded tissues for light microscope. Sci Instrum 11:11-12

Renault T, Haffner PH, Baudin Laurencin F, Breuil G, Bonami JR (1991) Mass mortalities in hatchery-reared sea bass (Lates calcarifer) larvae associated with presence in the brain and retina of virus-like particles. Bull Eur Assoc Fish Pathol 11:68-73

Skiftesvik AB, Bergh $\varnothing$ (1993) Changes in behaviour of Atlantic halibut (Hippoglossus hippoglossus) and turbot (Scophthalmus maximus) yolk-sac larvae induced by bacterial infections. Can J Fish Aquat Sci 50:2552-2557

Yoshikoshi K, Inoue K (1990) Viral nervous necrosis in hatchery-reared larvae and juveniles of Japanese parrot-fish, Oplegnathus fasciatus (Temminck \& Schlegel). J Fish Dis 13:69-77

Manuscript first received: October 10, 1996

Revised version accepted: February 14, 1997 